\title{
Strontium balance in breast-fed babies
}

\author{
BY G. E. HARRISON, ALICE SUTTON AND HILDA SHEPHERD \\ Medical Research Council Radiobiological Research Unit, Harwell, Didcot, Berks. \\ AND ELSIE M. WIDDOWSON \\ Medical Research Council Department of Experimental Medicine, \\ University of Cambridge \\ (Received 9 September 1964-Accepted 9 October 1964)
}

We have already reported that, in 3-day balance studies on male breast-fed babies between the 6th and gth day after birth, more strontium was excreted than ingested, though the balance for calcium and phosphorus was positive (Widdowson, Slater, Harrison \& Sutton, I960). More recently, measurements of the $\mathrm{Ca}, \mathrm{Sr}$ and phosphate balances in older bottle-fed infants have been reported by others (Lough, Rivera \& Comar, 1963; Straub, Kahn, Wellman, Telles \& Seltzer, 1964). In these investigations, the infants were from 4 to 7 weeks old. For Sr, the results were difficult to interpret because in the earlier study tap water, which contains $\mathrm{Sr}$, was accidentally used as a dietary additive before the experimental period, and in the later study the diapers used for the collection of the urine and faeces had a relatively high Sr content.

Interest in mineral balance in the newborn, particularly that of Sr (Comar, I96I; Loutit, I960), has stimulated us to extend our original observations, which are, so far as we are aware, unique not only because the infants were breast-fed, but also because separate values were obtained for the intake as well as the urinary and faecal output of $\mathrm{Sr}$ in the very young.

The Sr and Ca balance for three babies 6 weeks old was also measured, so that the net retention and absorption of Ca could be compared in the two age groups.

\section{EXPERIMENTAL}

\section{Subjects}

The babies were born at the Maternity Hospital, Mill Road, Cambridge. They had been fully breast-fed from birth. Each infant was weighed before and after each feed during the 3 -day balance trials, and the milk intakes were obtained by difference. There was no regurgitation.

Breast milk was expressed from each mother during the balance study for the determination of $\mathrm{Sr}$ and $\mathrm{Ca}$. The method used for the collection of urine and faeces passed by the babies has already been described (Slater, 196I).

\section{Analytical methods}

General. In our earlier experiments the breast milk was analysed for $\mathrm{Sr}$ when sufficient could be obtained from the mother. Thus, analyses were made for four out of 
nine nursing mothers during the balance study. Sufficient milk was obtained from all the mothers for the determination of $\mathrm{Ca}$. The ratio, $\mathrm{Sr}: \mathrm{Ca}$ was also determined in a pooled sample from fifteen other mothers. When the $\mathrm{Sr}$ intake was not determined directly, it was calculated from the total Ca intake of the infant and the mean value of the ratio $\mathrm{Sr}: \mathrm{Ca}$.

In the measurements reported here, about $30 \mathrm{ml}$ of milk from each mother, about one-third of the bulked faecal output and portions of about $300 \mathrm{ml}$ from the bulked urine passed over 3 days by each infant were reserved for $\mathrm{Ca}$ and $\mathrm{Sr}$ determinations. The milk and faecal homogenates were dried and thermally ashed, and the ash was dissolved in dilute hydrochloric acid.

$\mathrm{Ca}$ was determined, as before, by a modification of the method of Clark \& Collip described by Economou-Mavrou \& McCance (1958).

$\mathrm{Sr}$ determinations. $\mathrm{Sr}$ with $\mathrm{Ca}$ was precipitated from milk, faecal ash or a concentrate of acidified urine by adding excess of ammonium oxalate, the $\mathrm{pH}$ being adjusted to about 7 by adding ammonium hydroxide. The resulting precipitate of mixed oxalates was chilled for $\mathbf{2} \mathrm{h}$, separated, and washed with dilute ammonium hydroxide before being dried.

$\mathrm{Sr}$ in the oxalate extracts was determined by one of two different methods, depending on the amount of Sr present. In the samples of faecal ash, which contained more than $5 \mu \mathrm{g}$ of $\mathrm{Sr}$, the determination was carried out by the additive standard flame-spectrophotometric method described by Harrison (1958). The faecal oxalates were redissolved in nitric acid and $\mathrm{Sr}$ was reprecipitated as strontium nitrate further to purify the extract before the measurement. For milk and urine samples, which contained only $\mathrm{I}$ or $2 \mu \mathrm{g}$ of $\mathrm{Sr}$, the measurement was carried out by neutron activation analysis. The procedure was similar to that described by Harrison \& Raymond (1955). A weighed portion of oxalate extract from milk or urine was irradiated for about $2 \frac{1}{2} \mathrm{~h}$ in a neutron flux of about ${ }^{1} 0^{12}$ per $\mathrm{cm}^{2}$ per sec at the same time as a weighed amount of pure strontium carbonate. In all analyses the chemical yield of $\mathrm{Sr}$ was determined radiochemically by adding ${ }^{85} \mathrm{Sr}$ (about $150 \mathrm{pc}$ ) to the original sample. The ratio of the final to the initial count-rate of ${ }^{85} \mathrm{Sr}$ was used to assess the chemical recovery.

'Blank' determinations were made for $\mathrm{Sr}$ on washings from the equipment used to collect the excreta and on the carmine marker used in the faecal collection. The Sr content of each of these was less than $I \%$ of that in the relevant sample.

\section{RESULTS}

Table I gives the milk intake and urine output in $\mathrm{ml}$ for each of twelve babies over the 3-day balance study from the 6th day after birth and for three babies 6 weeks old. The concentrations of $\mathrm{Ca}$ and $\mathrm{Sr}$ in the milk and urine of each baby are also shown in the table.

There was considerable range in the observed values, especially for the $\mathrm{Ca}$ and $\mathrm{Sr}$ concentrations in the urine. However, the ratio of $\mathrm{Sr}$ to $\mathrm{Ca}$ in milk and urine showed a smaller range, mean values and their standard errors being $0.24 \pm 0.02$ (milk) and $I \cdot 16 \pm 0 \cdot 16$ (urine) for the younger group of babies. 
The $\mathrm{Ca}$ and $\mathrm{Sr}$ concentrations of mother's milk did not appear to change between I week and 6 weeks after birth, and changes in the $\mathrm{Ca}$ and $\mathrm{Sr}$ concentration of infant urine with age were equivocal.

Table I. Total milk intakes and urinary outputs of breast-fed babies, and calcium and strontium concentrations in milk and urine

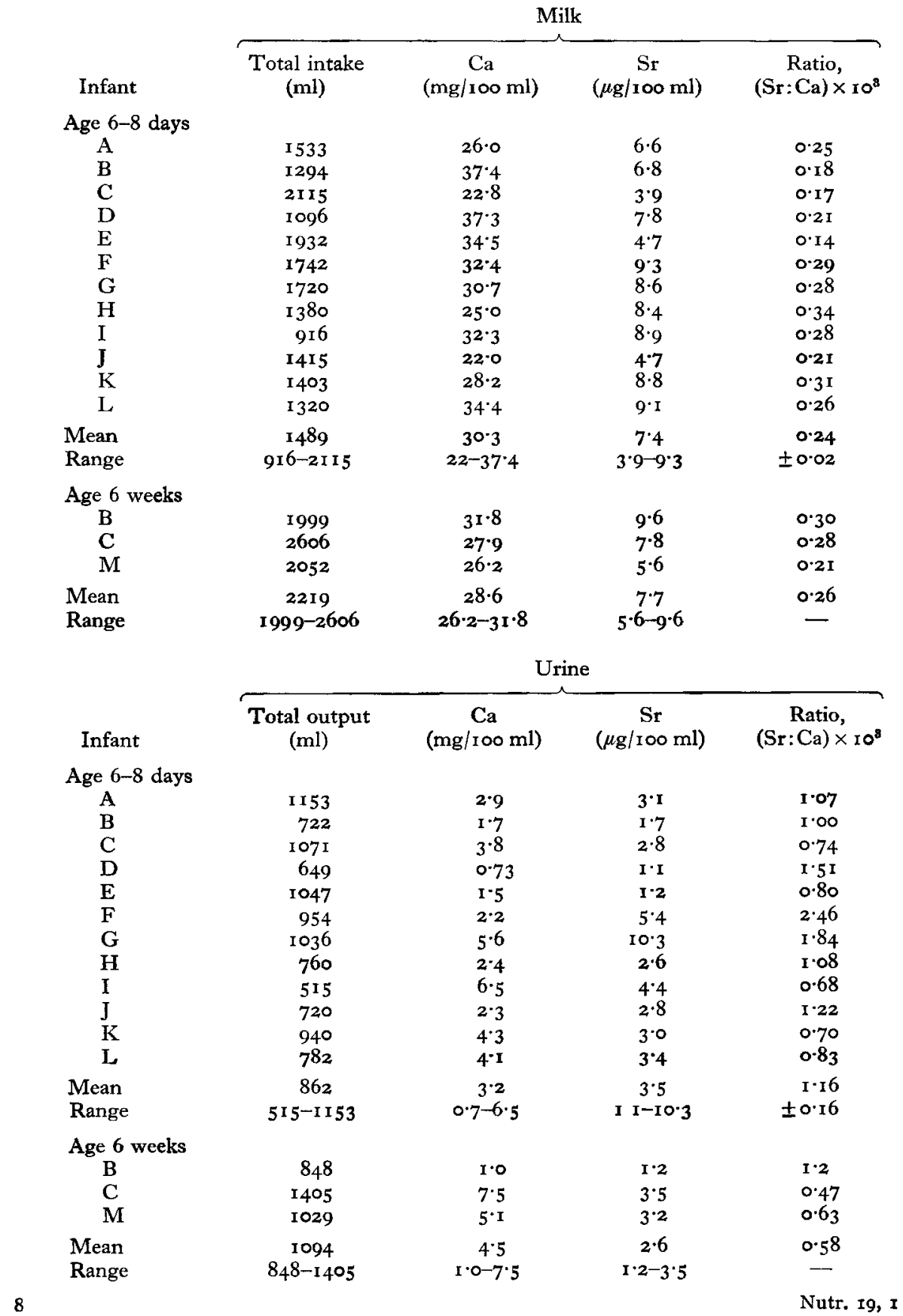




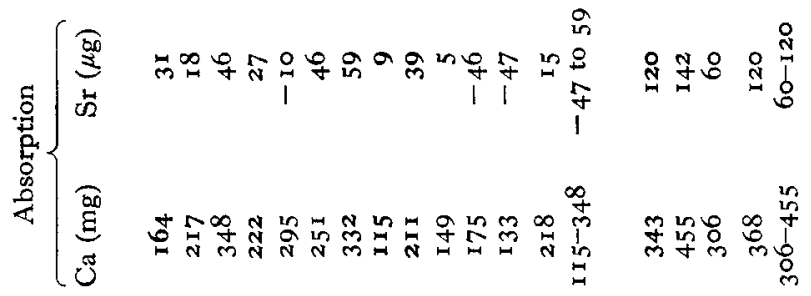

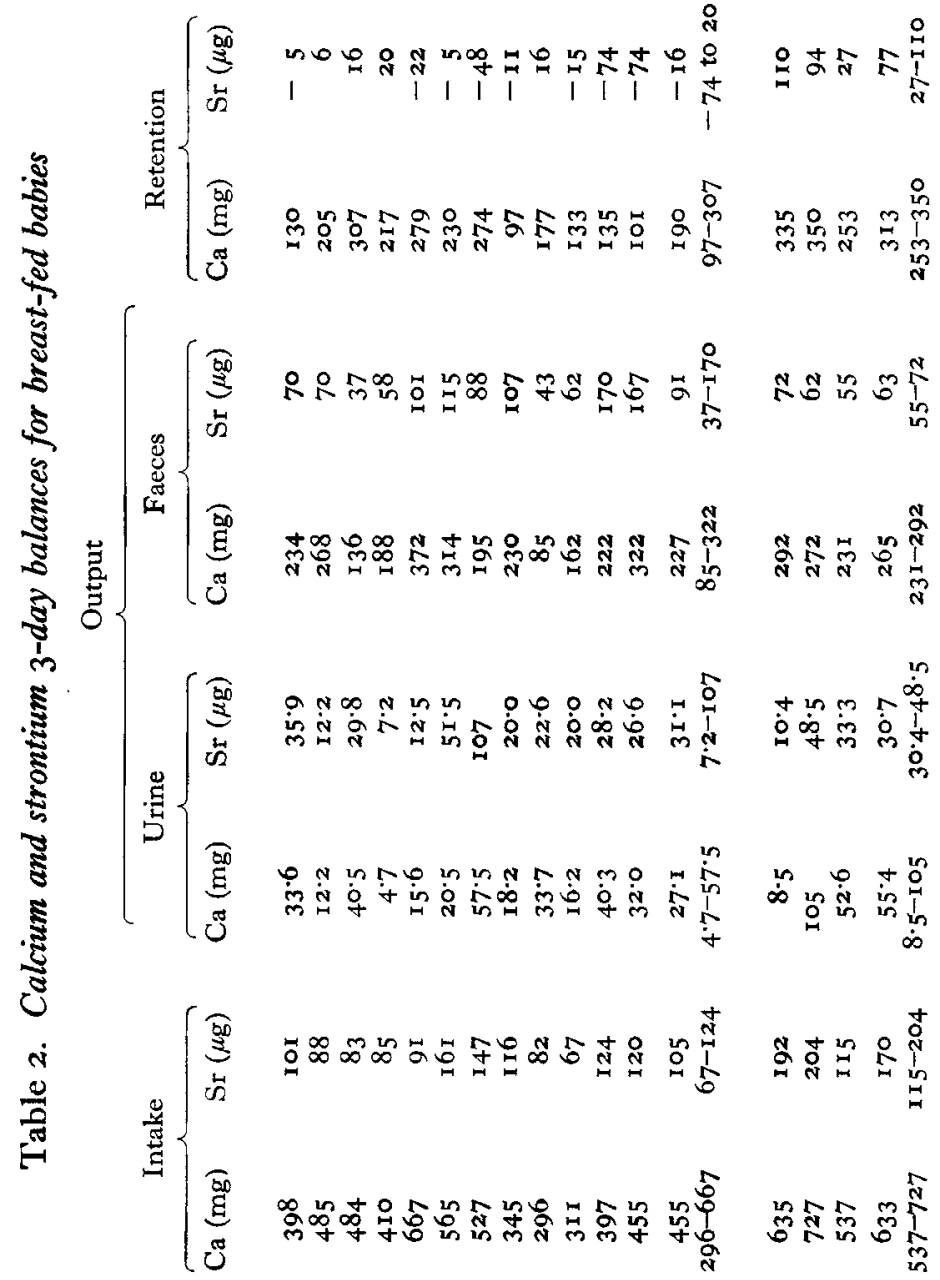

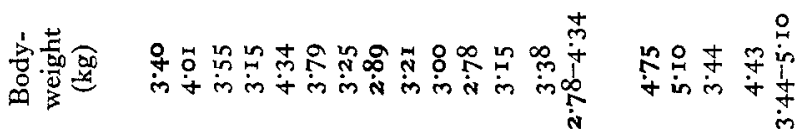

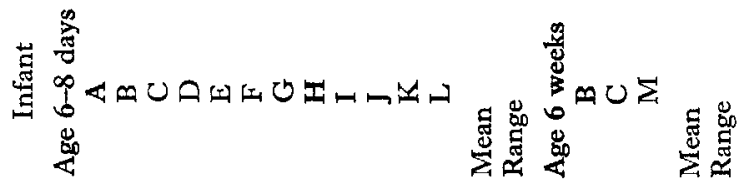


Table 2 shows the body-weight in $\mathrm{kg}$, with the intake and the urinary and faecal outputs of $\mathrm{Ca}$ and $\mathrm{Sr}$, over the 3-day balance period for each baby. The retention and apparent absorption of $\mathrm{Ca}$ and $\mathrm{Sr}$ are also shown. Retention is expressed as intake minus total output (urine plus faeces) and apparent absorption as intake minus the faecal output. Both retention and the apparent absorption were thus derived as differences between two relatively large quantities. In each of the latter there was a considerable range for the different babies, so that it is not surprising that there was a fairly wide distribution in the values obtained for the retentions and apparent absorptions of $\mathrm{Ca}$ and $\mathrm{Sr}$. However, for the younger group, in only four out of twelve was the retention of Sr positive. The mean retention was - I $6 \mu$ g over the 3 -day period, or about $-\mathrm{I} \cdot 7 \mu \mathrm{g} / \mathrm{kg}$ day. For each of the babies 6 weeks old, however, there was a positive retention of $\mathrm{Sr}$, the mean being $+77 \mu \mathrm{g}$, or $5.8 \mu \mathrm{g} / \mathrm{kg}$ day. The retention of $\mathrm{Ca}$ was markedly positive in all of them.

\section{DISCUSSION}

The mean urinary outputs and body retentions of $\mathrm{Ca}$ by breast-fed babies as reported by us earlier (Widdowson et al. 1960 ) were 5.3 and $+20 \mathrm{mg} / \mathrm{kg}$ day and 14 and $-20 \mu \mathrm{g} / \mathrm{kg}$ day for $\mathrm{Sr}$, compared with 2.7 and $+19 \mathrm{mg} / \mathrm{kg}$ day for $\mathrm{Ca}$ and $3 \cdot \mathrm{r}$ and $-\mathrm{I} \cdot 7 \mu \mathrm{g} / \mathrm{kg}$ day for $\mathrm{Sr}$ in the measurements reported here.

In this study, the urinary output of Sr for breast-fed babies was determined by neutron activation analysis. It is our experience that this more sensitive but more laborious method of assay is necessary when the sample contains less than $5 \mu \mathrm{g}$ of $\mathrm{Sr}$ (Harrison, 1958). However, in the earlier assays the Sr content of the urine samples from the breast-fed babies often appeared to contain more than $5 \mu \mathrm{g} \mathrm{Sr}$, so that the assays were made by flame spectrophotometry. A large 'off-line' reading was observed on the spectrophotometer in the measurement of the Sr emission from these samples. We regard the present measurements of the Sr content in urine by neutron activation analysis as more accurate than the values found earlier, and the smaller negative $\mathrm{Sr}$ balance now obtained for the breast-fed babies is thus regarded as more reliable.

One possible artifact that would produce a negative balance would be the presence of meconium, found to contain 2.7 ppm of Sr (Widdowson, McCance, Harrison \& Sutton, 1962), in the faeces. But to account for the mean negative balance for $\mathrm{Sr}$ ( $-\mathrm{I} 6 \mu \mathrm{g}$ in 3 days) the meconium content of each day's faeces would have to be $2 \mathrm{~g}$. Although meconium was visible in certain stools even at 6 days after birth, it is improbable that the daily output approached this level.

In Britain, over the last few years, bones taken at autopsy from babies of various ages have been assayed for stable $\mathrm{Sr}$ and $\mathrm{Ca}$ as part of the national survey of any internal contamination of the population by ${ }^{90} \mathrm{Sr}$. The results have been reviewed recently by Bryant \& Loutit (1964), who conclude from the data for infants 0 - to I-day-old dying during $1959-6 \mathrm{r}$ that the ratio for $\mathrm{Sr}: \mathrm{Ca}$ in bone is significantly greater in the London area than in Wales or Lancashire. Mole (1965) has emphasized further the dependence on the place of birth of the $\mathrm{Sr}$ : Ca ratio in bone of the newborn and the change in the ratio with age. A recent analysis of the results for the ratio 
$\mathrm{Sr}: \mathrm{Ca}$ in the bone of infants born in the London area between $1957-60$ and $1960-2$ by R. H. Mole (1964, personal communication) is shown in Table 3. These results suggest that there is a slight fall in the ratio during the first few days after birth, followed by a rise in the ratio for infants more than 8 days old. There is no record of how many of these babies were breast-fed. It was shown in the original investigation (Widdowson et al. 1960) that bottle-fed babies were in positive balance for Sr as well as $\mathrm{Ca}$, so that the ratio of $\mathrm{Sr}$ to $\mathrm{Ca}$ would be expected to increase for such infants. Thus the slight fall in the ratio shown in Table 3 during the ist week after birth might well have been greater had all the babies been breast-fed.

Table 3. Mean values with their standard errors for the ratio of strontium to calcium (expressed as $\mu g / g$ ) in bone from babies born in the London area

$\begin{array}{ccccc}\text { Year of birth } & \text { Stillborn } & 0-2 \text { days old } & 3-7 \text { days old } & 8-30 \text { days old } \\ 1957-60 & 221 \pm 12(24) & 206 \pm 17 \text { (10) } & 215(2) & 197 \pm 7(3) \\ 1960-2 & 261 \pm 17(16) & 219 \pm 12(19) & 288 \pm 43(4) & 308 \pm 23(6)\end{array}$

The numbers of subjects are given in parentheses.

Table 4. Calcium and strontium concentrations and the ratios of these concentrations in tissues, gut and contents of stillborn babies

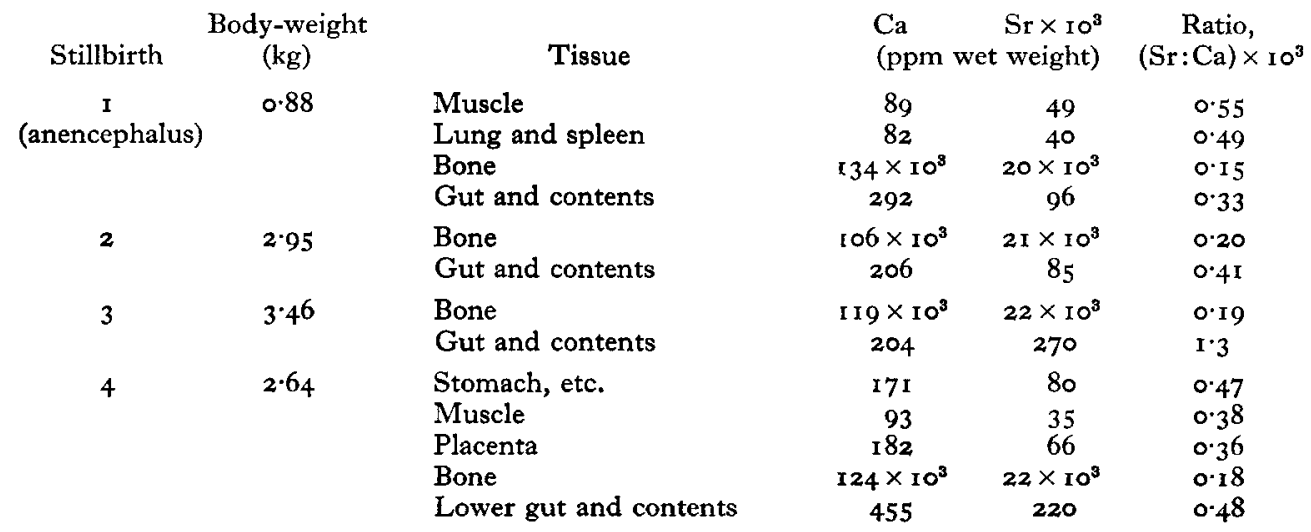

We have recently measured the $\mathrm{Sr}, \mathrm{Ca}$ and $\mathrm{P}$ contents of various tissues taken from stillborn babies. The $\mathrm{Ca}$ and $\mathrm{Sr}$ concentrations, as well as the ratio of $\mathrm{Sr}: \mathrm{Ca}$ in bone, gut and contents and soft tissue, are shown in Table 4 . It will be seen that the ratio $\mathrm{Sr}$ : Ca in bone varies from 0.15 to $0.20 \times 10^{-3}$, but that the ratio in other organs ranged from 0.34 to $0.55 \times 10^{-3}$ and that for the gut and contents from 0.41 to $1 \cdot 3 \times 10^{-3}$. It is therefore possible that the relatively high $\mathrm{Sr}: \mathrm{Ca}$ ratios in soft tissues are due to relatively high concentrations of $\mathrm{Sr}$ in foetal blood compared with that in foetal bone. High concentrations of $\mathrm{Sr}$ in foetal and maternal blood have also been reported by Rivera (1963). Any 'excess' $\mathrm{Sr}$ in foetal blood would be excreted in urine during the early postnatal period. By reference to Table $\mathrm{I}$ it will be seen that the mean ratio of $\mathrm{Sr}$ : Ca in urine of babies $6-8$ days old was $\mathrm{I} \cdot \mathrm{I} 6 \times 10^{-3} \pm 0 \cdot 16$, whereas for the 6 -weekold babies it was $0.5^{8} \times 10^{-3}$. If renal discrimination against $\mathrm{Sr}$ is unchanged in the 
first 6 weeks after birth, these results must mean that excess $\mathrm{Sr}$ is being eliminated in the urine of the 6-8 days old babies. Although a change in the output of Sr in the urine was detectable in breast-fed babies, it would not be measurable in bottle-fed infants for whom the daily intake of both $\mathrm{Sr}$ and $\mathrm{Ca}$ was several times greater.

\section{SUMMARY}

I. The calcium and strontium intakes and the urinary and faecal outputs have been measured over 3 days in twelve babies from the 6 th day after birth and in three babies who were 6 weeks old.

2. The mean $\mathrm{Sr}: \mathrm{Ca}$ ratio in the human milk received by the younger group of babies was $0.24 \pm 0.02 \times 10^{-3}$ and in the urine of the newborn $1 \cdot 16 \pm 0.16 \times 10^{-3}$. For the babies 6 weeks old, this milk ratio was $0.26 \times 10^{-3}$ and that for urine $0.58 \times$ I0 $0^{-3}$.

3. The mean negative balance for $\mathrm{Sr}$ was $-\mathrm{I} \cdot 7 \mu \mathrm{g} / \mathrm{kg}$ day for babies between 6 and 8 days old, although the $\mathrm{Ca}$ balance was always positive. The 6-week-old babies were in positive balance for $\mathrm{Sr}$ as well as for $\mathrm{Ca}$.

4. The negative balance for $\mathrm{Sr}$ was smaller than that obtained in an earlier study. Improvements in the assay of Sr, particularly in urine, are described and make the new results more reliable.

5. The negative Sr balance observed in young babies is not inconsistent with the results obtained for the $\mathrm{Sr}$ : $\mathrm{Ca}$ ratios in bones from stillborn babies or those dying in the first few days after birth.

6. A possible reason for a high urinary output of $\mathrm{Sr}$ in the newborn is discussed.

We would like to thank Dr Mole for providing the figures given in Table 3 and Professor R. A. McCance, FRS for his assistance with the preparation of the script. Our special thanks are also given to Miss S. H. McKeag, who was responsible for all the measurements and collections from the babies at the Maternity Hospital.

\section{REFERENCES}

Bryant, F. J. \& Loutit, J. F. (1964). Proc. roy. Soc. B, 159, 449.

Comar, C. L. ( 196r). Lancet, i, 950.

Economou-Mavrou, C. \& McCance, R. A. (1958). Biochem. F. 68, 573.

Harrison, G. E. (1958). Nature, Lond., r82, 792.

Harrison, G. E. \& Raymond, W. H. A. (1955). F. nuclear Energy, 1, 290.

Lough, S. A., Rivera, J. \& Comar, C. L. (1963). Proc. Soc. exp. Biol., N.Y., 112, 63x.

Loutit, J. F. (1960). Lancet, ii, 1448.

Mole, R. H. (1965). Brit. F. Nutr. 19, 13.

Rivera, J. (1963). Nature, Lond., 200, 269.

Slater, J. E. (1961). Brit. F. Nutr. 15, 83 .

Straub, C. P., Kahn, B., Wellman, H. N., Telles, N. C. \& Seltzer, R. A. (1964). International Atomic Energy Agency, International Labour Office and World Health Organization Symposium on Assessment of Radioactive Body Burdens in Man. Heidelberg, I I-16 May 1964. (In the Press.)

Widdowson, E. M., McCance, R. A., Harrison, G. E. \& Sutton, A. (r962). Lancet, ii, 373.

Widdowson, E. M., Slater, J. E., Harrison, G. E. \& Sutton, A. (1960). Lancet, ii, 941. 